\title{
Motifs and Impediments for the Harmonization of Accounting Regulations for Small and Medium-Sized Companies in the EU
}

\author{
Tamara Cirkveni \\ RRiF High School for Financial Management, Zagreb, Croatia
}

\begin{abstract}
Small and medium-sized companies in most EU countries form a considerable share in the total number of companies and are also an important development impeller of the entire economy. Therefore, one of the most essential goals of accounting authorities in the EU is accomplishing the harmonization of accounting regulations for these companies. In this paper, the author have discussed and explained the main motifs and impediments for this harmonization. One of the main motifs is a big span and complexity of international standards of financial reports which is allowed and even prescribed in many countries. Some of the main impediments are a lack of uniformity as far as criteria for classification of small and medium-sized companies according to size are concerned as well as the determining of limitations up to which the requirements in accounting standards for small and medium-sized companies should be set.
\end{abstract}

Keywords: IFRS for SMEs, accounting regulation, small and medium sized entities, motifs, impediments

\section{Introduction}

Efforts to "harmonize" accounting around the world began even before the creation of the International Accounting Standards Committee. Companies seeking capital outside of their home markets and investments internationally faced increasing problems resulting from national differences in accounting measurement, disclosure, and auditing (Choi, Frederick, Meek, \& Gary, 2008). In the last thirty years, this process has been mostly oriented on large entities. The bases of accounting regulation were made by the fourth and the seventh directive of the EU. However, they failed to obtain a desirable and expected level of financial reporting transparency and comparability.

The process of adoption of international financial reporting standards (IFRS) in both EU and non-EU countries has created further bases for establishing accounting regulations, especially for well-rated entities. The Regulation of the European Parliament and of the Council (1606/2002/EC dated July 19, 2002) (Retrieved July 20, 2010, from http://www.eur-lex.europa.eu) has had an important role in this process and it has also prescribed a required application of the IFRS for all entities which are rated on the EU financial market and which have been

Tamara Cirkveni, MSEc, Economy Department, RRiF High School for Financial Management.

Correspondence concerning this article should be addressed to Tamara Cirkveni, Vlaška 68, 10000 Zagreb, Croatia. E-mail: tamara@rrif.hr. 
preparing consolidated financial reports since May 1, 2005. This requirement has substantially influenced the acceptance of the IFRS as a frame of financial reporting for other (both well-rated and non-rated) entities in the EU member states as well as in African and Asian countries. Although these EU and IFRS directives have played a vital part in the establishment of the entire accounting regulation, their requirements are adjusted mostly for large entities which manage a sufficient number of professional accountants and whose beneficiaries of financial reports need more information about their management. The requirements for small and medium-sized entities, which account for 95\% (Klikovac, 2009) of all entities in most EU countries, were therefore placed in the background, i.e., they were left to national accounting regulations. Due to those reasons, some countries accepted the IFRS even for small and medium-sized entities (e.g., Malta, Cyprus), while other countries have created national standards in order to reduce the requirements in the financial reporting for small and medium-sized entities (e.g., Great Britain, Slovenia, Ireland, Sweden). Due to the fact that it is obvious that the IFRS are too complicated to be applied for small and medium-sized entities, the motifs for the harmonization of the accounting regulations for small and medium-sized entities in the EU are numerous. Seven years ago International Accounting Standards Board (IASB) has therefore started creating global accounting standards for those entities as a part of the project "International standards for small and medium-sized entities" (IFRS for SMEs). A lot of problems occurred in that process, the most important were the lack of uniformity as far as criteria for classification of small and medium-sized entities are concerned as well as the determining of limitations up to which the requirements in accounting standards for small and medium-sized companies should be set. Nevertheless, the IASB published the IFRS for SMEs in July 2009. Ultimately, the open question that still remains to be answered is whether the European Commission will and in which scope adopt these standards as a constituent part of accounting legal regime in the EU.

\section{The Characteristics of Accounting Regulative in EU}

The European Union (the EU) is a regional organization of European states through which its members accomplish common goals such as well-balanced economic and social development, high rate of employment as well as the protection of citizens' rights and interests. Since January 1, 2007, the EU consists of 27 member states with the population of approximately half a billion people (Retrieved July 20, 2010, from http://www.entereurope.hr). The accounting legal regime in the EU is comprised of directives and regulations, and regulatory bodies that regulate accounting at the EU level are: European Parliament, Council of the European Union, European Commission, European Financial Reporting Advisory Group and Accounting Regulatory Committee.

The accounting system of every EU member state as well as of those states which aspire to that status is based on regulations and directives of the EU. Beside them, an important role is played by decisions, recommendations and opinions which are passed by the EU legislation. Regulations which are passed at the EU level are binding for application in all EU member states, i.e., individual adoption for their application is not needed in the EU member states. At the EU level, several regulations of the European Parliament and of the Council, as well as of the European Commission have been passed and are referred to the accounting regulative. The regulation that defined the beginning of harmonization of the accounting regulative in the EU is the Regulation of the European Parliament and of the Council (1606/2002/EC dated July 19, 2002). According to this 
regulation all entities which are rated in the financial market of the EU and which prepare consolidated financial reports are bound to apply the IFRS since January 1, 2005.

The EU directives are adopted by the legislation of every member state. Although all EU member states are bound to adopt the directives, it does not mean that the institutions within the member state have to comply with the directives if their content is not prescribed by their legislature. The most important directives which edit accounting area are the fourth and the seventh directive, as well as the directives which define the financial reporting in the banks and insurance companies. The fourth directive has harmonized the appearance of balance, as well as of the profit and loss account, and it has also defined the minimum of information that the notes to the financial statements have to contain. An important base for the comparability of information in the financial reporting has therefore been created. The seventh directive has defined the entities which should prepare the consolidated financial reports and that has standardized the requirements which are referred to those reports. However, the success of EU harmonization efforts has been debated. For example, member states generally did not scrap their existing accounting rules when adopting EU directives. Another issue is the scope to which member states enforced compliance with the directives (Walton, 2007).

The prerequisite for a complete acceptance and spread of the IFRS and which is published by the IASB was made by the directive. Current application of the IFRS in the world shows that the IFRS are accepted world-wide, that many countries use them as a basis for their national standards and that they are accepted by numerous stock-markets and controllers which allow domestic or foreign entities to deliver the financial reports prepared according to the IFRS (Choi, Frederick, Meek, \& Gary, 2008). The application of the IFRS during the preparation of consolidated financial reports for non-rated entities is allowed by/in the majority of EU member states. For the individual financial reports of the EU member states, the application of the IFRS is somewhat different. Therefore, in ten EU member states the use of IFRS is not allowed (e.g., Austria, Belgium, the Czech Republic, France etc.). The above application suggests that in the majority of the EU states, IFRS are accepted when consolidated financial reports are prepared, and to a lesser scope when individual financial reports for non-rated entities, i.e., for small and medium-sized entities, are prepared.

The directive provides the member states to allow the application of the IFRS to the entities during the preparation of the individual financial reports, as well as to entities which are not rated in the regulated capital market (Tadijančević, 2005), i.e., small and medium-sized entities. Such a demand can be justified due to the fact that the IFRS meet the requirements of the external users with the goal of truthful and fair display of properties, management liabilities and results. However, the complexity of their requirements and solutions in some issues are not appropriate for the usage in the small and medium-sized entities. Therefore, in the majority of countries national legislature for the financial reporting of the small and medium-sized entities is applied. The countries which possess prescribed standards for small and medium-sized entities, and the EU members are Great Britain and Slovenia. Unlike the IFRS, the EU directives refer to all entities, even the small and medium-sized entities. The essential role in the financial reporting of the small and medium-sized entities is played by the fourth directive that beside the rules for the preparation and publication of the financial reports, recommends abbreviated financial reporting for those entities. Unfortunately, that proposal was not sufficient for solving the problem of financial reporting for small and medium-sized entities. 


\section{The Harmonization of Accounting Regulative for Small and Medium-Sized Entities}

Small and medium-sized entities are an important promoter of the entire EU economics, and it is understandable that for some time a question is asked whether it is needed and how to harmonize the accounting regulative for those entities. Numerous accounting organizations have tried to answer these questions, but the central role was held by the IASB which has recognized the complexity of the application of the complete IFRS for small and medium-sized entities and which has also started the project to create the standards of financial reporting for small and medium-sized entities. For the main motifs of this action, the IASB has, beside the complexity of the IFRS, highlighted the fact that the adoption of global standards for small and medium-sized entities is necessary due to better protection of foreign suppliers, foreign banks which grant them loans, and due to foreign investors to whom the global accounting standards will ensure a desired compatibility (Retrieved July 18, 2010, from http://www.iasb.org). Despite all that, during the creation of global accounting standards there were numerous obstacles which had to be overcome.

The basic problem which complicates the harmonization of financial reporting for small and medium-sized entities is the criteria for classification of entities according to their size. It is enough just to be reminded that the fourth directive, the European commission and the national legislature of EU member states prescribe different amounts for the quantitative classification of entities (the sum of the balance sheet, total income, number of employees). On the other hand, the IASB has, during the defining of the standards scope for small and medium-sized entities, chosen the qualitative characteristics, i.e., the defining of the public liability during the classification of small and medium-sized entities. The usage of different terminology which denotes the same term (small and medium-sized entities) is equally indisputable. Besides, numerous authors as the main argument against separation of financial report for small and medium-sized entities from the one for large entities state the need for universality, comparability and reliability of the financial reports for all categories of entities. It is also vital to take into account that in some countries (e.g., Germany) financial reports traditionally serve also for the needs of informing and determining the profits (for distribution), and the IFRS are inappropriate for that function, especially because they are not oriented towards the precautionary principle, whose goals are the maintenance of capital and the protection of investors (2005).

In the process of harmonization of financial reporting an important role belongs to the IASB which has already in 2001 with Standards Advisory Council (SAC) for the first time considered the need for creating accounting standards for small and medium-sized entities, and two years later (i.e., 2003) it launched their creation. In the process of developing the IFRS for SMEs, the IASB conducted an extensive world-wide debate. Working group comprised of forty members - experts cooperated with the IASB on the structure and content of the IFRS during different development stages. Standards draft was published in 2007 and it was translated into five languages which contributed to the widening of the circle of experts involved in the debate ${ }^{1}$. It has also been tested on more than 100 small entities in 20 countries resulting in a further simplification of standards.

Final version of the IFRS for SMEs was published in July 2009. The bottom line is that the SMEs standards actually represent a shortened form of the IFRS (the scope is reduced for 90\%). Certain requirements which are considered inappropriate for the application in small and medium-sized entities are not contained in the IFRS for

\footnotetext{
${ }^{1}$ Mrša, Josipa. Iz odbora za MRS-Objavljeni su IFRS-a za mala i srednje velika poduzeća. RRiF, 2009., br. 08/09., str. 49.
} 
SMEs (see Table 1).

Table 1

IFRS Requirements Which Are Not Included in the IFRS for SMEs

\begin{tabular}{|l|l|}
\hline IAS 33 & Earnings per share \\
\hline IAS 34 & Intern in financial reporting \\
\hline IFRS 5 & Non-current assets held for sale and discontinued operations \\
\hline
\end{tabular}

Besides, in the IFRS for SMEs simpler variants are involved in subsequent valuation of tangible fixed assets as well as simplified recognition and establishment of financial assets.

The recognition of tax assets and deferred tax liabilities is also simplified. The IFRS for SMEs consist of 35 sections and a glossary (Retrieved July 25, 2010, from http://www.iasb.org), and they should be applied by the entities which do not have "public liability".

\section{Obstacles for a Possible Application of the IFRS for SMEs}

Despite the fact that the IFRS for SMEs are supported by numerous international organizations, the EU support is still debatable. In fact, in September 2007 Charlie McCreevy, the European Commissioner for Internal Market and Services declared that the IFRS Draft for SMEs was not simplified enough to be appropriate for application in most small and medium-sized entities. Due to these reasons numerous efforts were subsequently made in order to simplify and adjust the accounting requirements according to the requirements of small and medium-sized entities. The EU commission has decided to conduct a consulting research (Retrieved June 20, 2010, from http://www.ec.europa.eu/internal market/consultations/2009/ifrs for sme en.htm) about the need to simplify the directives' demands in order to create the basis for the application of the IFRS for SMEs. One of the important questions of the research was to determine whether the IFRS for SMEs appropriate for the application in the EU. The majority of respondents answered affirmatively (13 of 22 countries). The countries which support the application of the IFRS for SMEs underline the enhanced comparability of information in financial reports since the application of these standards, the attraction of foreign capital, and therefore the reduction of capital expense due to application of universal accounting standards as main arguments for their application. On the other hand, some respondents think that the IFRS for SMEs are too complex for application in small entities, i.e., that the consequence of the application of these standards will be contradictory due to high expenses of the preparation for their application. An overview of the most important arguments for and against the application of the IFRS for SMEs is shown in Table 2.

Table 2

An Overview of Arguments for and Against the Application of the IFRS for SMEs According to the Respondents

\begin{tabular}{|l|l|}
\hline Arguments for IFRS for SMEs & Arguments against IFRS for SMEs \\
\hline $\begin{array}{l}\text { enhanced harmonization and comparability of information in } \\
\text { financial reports }\end{array}$ & $\begin{array}{l}\text { the duplication of administrative burden for those entities } \\
\text { can result in double financial reporting }\end{array}$ \\
\hline reduced capital expenses & $\begin{array}{l}\text { they are not useful to the entities which do business "locally" the } \\
\text { frequency of changes in the accounting regulative }\end{array}$ \\
\hline the usage of an "unique accounting language" &
\end{tabular}

Respondents also held a wide range of views on how to deal with incompatibilities between the Accounting 
Directives and the IFRS for SMEs. Some countries implied that a mechanism should be formed which would maintain the compatibility of accounting standards and directives and enable their alternations. Others suggested that conflicts should be resolved on a case by case basis by national authorities, or that priorities should be established in the framework of the Directives. Finally, some respondents considered that the IFRS for SMEs should not be applied in case of incompatibility.

Due to all these reasons the European Financial Reporting Advisory (EFRAG) conducted a research (Retrieved July 20, 2010, from http://www.efrag.org/newa/detail.asp?id=548) which was directed to analyse the compatibility of the IFRS for SMEs and of the fourth and the seventh directives. The aim of this research was to determine the areas of incompatibility of the IFRS for SMEs and of the directives. According to the conclusion of the EFRAG the incompatibilities in the IFRS for SMEs are determined in numerous areas (see Figure 1).

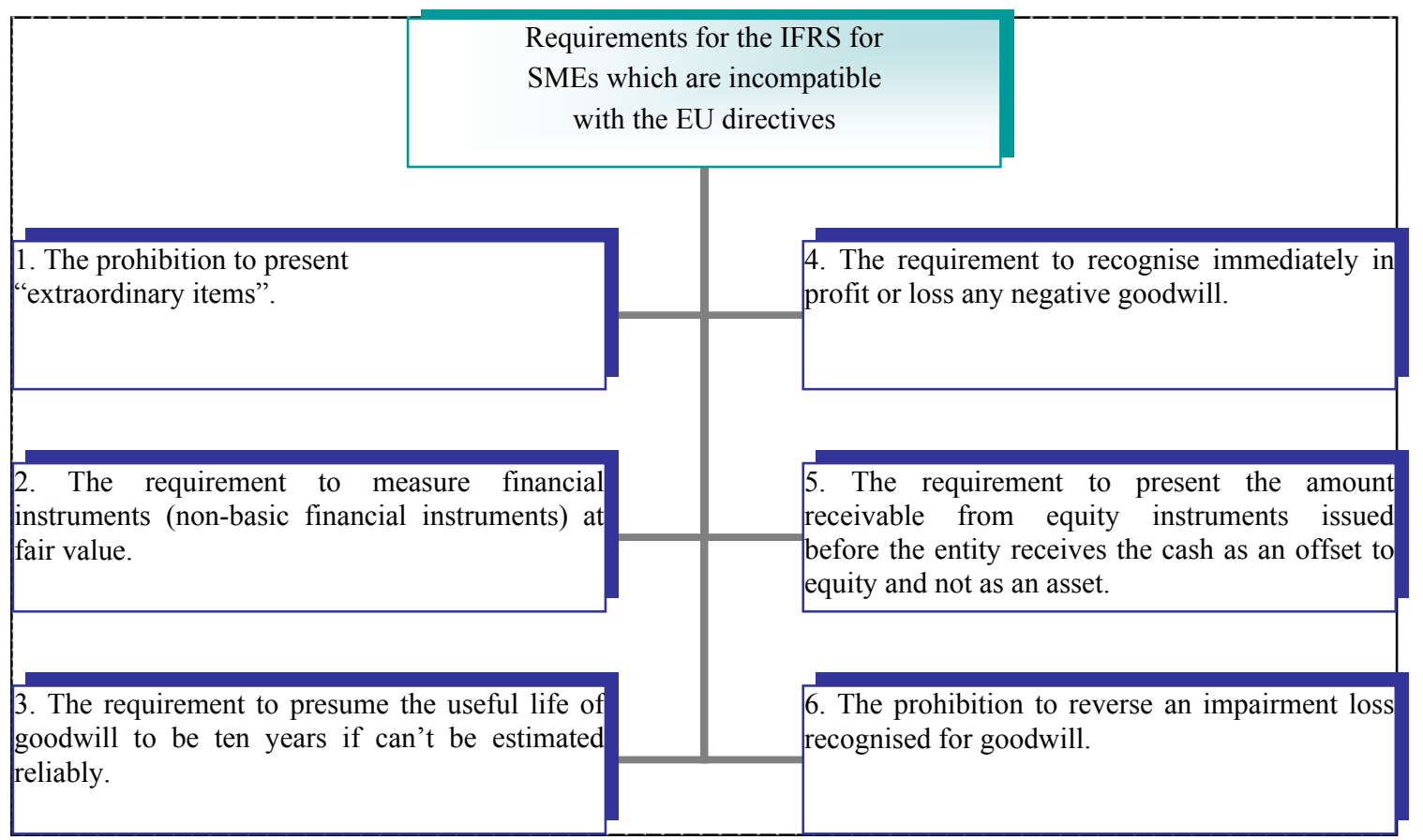

Figure 1. An overview of requirements for the IFRS for SMEs which are incompatible with the EU directives.

Data about the requirements for the modernization of the directives were gained due to the consultations conducted by the EFRAG and IASB. Numerous interest groups consider that the directives should continue to be the framework of the financial reporting in the EU and that they should prescribe the preparation of reports about the money flow and minimal information which should be presented in the notes. Other interest groups intercede for the making of directives which are drafted on the principles and not on the detailed elaboration of the financial reports' structure. When defining the value of the items which are shown in the financial reports, numerous groups consider that the application of fair value method represents a great burden for small entities and that it is in contradiction with the basic principle "think small first" on which reviewed assets should be based. In order to enable quality accounting information, many who are involved think that the extraordinary items should again be placed in the financial reporting frame. All the provided requirements refer to the need for further consultations and debates in order to coordinate the directives' prescriptions with the IFRS requirements and the IFRS for 
SMEs requirements, all with the purpose of creating a unique accounting regulation for all entities.

\section{Conclusion}

Motifs for the harmonization of the accounting regulation for small and medium-sized entities are multiplying due to the process of globalization. However, there are also many obstacles which have appeared in this process. One of the obstacles is the acceptance of new solutions in the countries which have solved the problem of the requirements' scope in the IFRS by adopting national accounting standards for small or small and medium-sized entities. Another obstacle is the act of defining the criteria for classification of small and medium-sized entities, i.e., defining whether those are just the entities which do not have the public liability, as the IASB suggests. The application of fair value and extraordinary items in the accounting standards for small and medium-sized entities is also relevant in determining the requirements which are appropriate for the application in these categories of entities. The determination of scope and limitations is a very complex work, therefore it is not surprising that the process of adopting the IFRS-a for SMEs has lasted for seven years and that it has not resulted in the standards whose requirements were entirely accepted by the European commission and numerous interest groups which were involved in the debates related to the requirements of those standards. The demand of coordination of the accounting regulations has imposed the demand of coordination of the IFRS for SMEs with the directives whose prescriptions are based on the fundamental accounting principles which have created the basis for the harmonization of the accounting regulation.

\section{References}

Anonymous. (2005). Problems and opportunities of an international financial reporting standard for small and medium-sized entities. The EAA FRSC's Comment on the IASB's Discussion Paper. Accounting in Europe, 2, 23-45.

Anonymous. (2010). EFRAG Compatibility analysis: IFRS for SMEs and the EU Accounting Directives. Retrieved July 20, 2010, from http://www.efrag.org/newa/detail.asp?id=548

Basis for Conclusions on Exposure Draft. (2007). London. IASB. Retrieved July 18, 2010, from http://www.iasb. org

Choi, F. D. S., \& Meek, G. K. (2008). International accounting. Pearson Prentice Hall.

Klikovac, A. (2007). Financijsko izvještavanje u Europskoj uniji-komparativan prikaz. Ekonomski pregled. Mikrorad. Zagreb.

Klikovac, A. (2009). Financijsko izvještavanje u EU: Harmonizacija financijskog izvještavanja za mala i srednja društva. Mate: Zagreb.

Mrša, J. (2009). Iz odbora za MRS-Objavljeni su IFRS-a za mala i srednje velika poduzeća. RRiF, 08/09.

Ramljak, B., \& Žager, K. (2002). Potreba i iskustva drugih zemalja u razvoju računovodstva malih i srednjih poduzeća. zbornik radova XXXVII. Simpozija Pula, HZRIFD, Zagreb.

Smrekar, N. (2009). Usklađivanje nacionalne i međunarodne regulative financijskog izvještavanja malih i srednjih poduzeća. zbornik Ekonomskog fakulteta Zagreb. Mikrorad, Zagreb.

Tadijančević, S. (2005). Usklađenost financijskog izvještavanja i revizije u Hrvatskoj s pravnom stečevinom EU-a. zbornik radova XL. Simpozija Pula. HZRIF. Zagreb.

Walton, P. (2007). European Harmonization, International Finance and Accounting Handbook. 55.

Žager, K., et al. (2009). Računovodstvo malih i srednjih poduzeća. Mikrorad. Zagreb. 